\title{
Weekly Rainfall Analysis by Markov Chain Model in Samastipur District of Bihar, India
}

\author{
Pappu Kumar Paswan ${ }^{1 *}$, Ved Prakesh Kumar ${ }^{2}$, Andhale Anil Nanasaheb ${ }^{3}$ \\ and Abhishek Pratap Singh ${ }^{4}$ \\ ${ }^{1}$ Krishi Vigyan Kendra, Purnea, Bihar, India \\ ${ }^{2}$ College of Agricultural Engineering, Dr.R.P.C.A.U, Pusa, Samastipur, India \\ ${ }^{3}$ Department of Soil and Water Conservation Engineering, College of Agricultural \\ Engineering and Technology, Junagadh Agricultural University, India \\ *Corresponding author
}

\section{Keywords}

Weekly Rainfall, Markov Chain

Model, Onset and

Withdrawal of

Rainfall

\section{Article Info}

Accepted:

05 April 2020

Available Online:

10 May 2020

\begin{abstract}
A B S T R A C T
The historical rainfall data for the period of 22 years (19981-2019) of Samastipur district in Bihar were analyzed weekly rainfall data by using Markov chain model and initial and conditional probabilities were estimated for $10 \mathrm{~mm}$ and $20 \mathrm{~mm}$ rainfall amount. the initial probability of getting $10 \mathrm{~mm}$ rainfall during $23^{\text {th }}$ to $42^{\text {th }}$ SMW are more than $60 \%$ except $39^{\text {th }}, 41^{\text {th }}$ and $42^{\text {th }}$ SMW. Conditional probabilities of wet week preceded by another wet week of getting $10 \mathrm{~mm}$ rainfall during 23th to 40th SMW were 50\% and more. initial probability of getting $20 \mathrm{~mm}$ rainfall during $23^{\text {th }}$ to $38^{\text {th }}$ SMW are more than $45 \%$ (Table 1.) whereas conditional probability of wet week preceded by another wet week of getting $20 \mathrm{~mm}$ rainfall during $23^{\text {th }}$ to $38^{\text {th }}$ SMW were $45 \%$ and more except $30^{\text {th }}$ and $35^{\text {th }}$ SMW. consecutive dry and wet week revealed that chances of occurrence of $10 \mathrm{~mm}$ and $20 \mathrm{~mm} 2$ consecutive dry weeks are $0-54.55 \%$ and $0-59.09 \%$ respectively whereas 2 consecutive wet weeks are $0 \%-86.36 \%$ and $0-81.82 \%$ respectively from $23^{\text {th }}$ to $42^{\text {nd }}$ SMW respectively. The probability of $10 \mathrm{~mm}$ and $20 \mathrm{~mm}, 3$ consecutive dry weeks are $0-54.55 \%$ and $0-59.09 \%$ respectively whereas 3 consecutive wet weeks are $0-72.73 \%$ and $0-63.64 \%$ respectively from $23^{\text {rd }}$ to $42^{\text {th }}$ SMW respectively
\end{abstract}

\section{Introduction}

Agriculture development in Bihar state is to a large extent dependent of water. A large portion of the water in Bihar state (both surface and ground water) is consumed by the agricultural sector for irrigation. The state has an area of 93.60 Lakh ha, the net area sown is
56.38 lakh ha and gross activated area is 79.46 lakh ha. The net sown area in Bihar is $60 \%$ of its geographical area. (EconomicSurvey- 2012) Dynamic Ground Water Resources: Annual Replenishable Ground water Resource 29.19 BCM, Net Annual Ground Water Availability 27.42 BCM, Annual Ground Water Draft 10.77 BCM, 
Stage of Ground Water Development 39\%. The distribution of rainfall is very much erratic and uneven, so flood and droughts are occurring frequently in different regions of the state. Thus, the agricultural production is highly unstable.

Even during monsoon season, the state suffers from simultaneous problems of disposal of surplus water caused by heavy storms in some parts and water deficit due to lack of adequate rainfall in other parts. (Parthasarathy, 2009) The area is situated at the west of the college of Agricultural Engineering, Dr Rajendra Prasad Central Agricultural University, Pusa, Samastipur and falls under the jurisdiction of Gandak Command.

Pusa Farm is situated in Samastipur district of north Bihar on south of river Burhi-Gandak. It has a latitude of 250 29' North and a longitude of $83048^{\prime}$ East at an altitude of 52.92 meter above sea level. Coincidence of dry spells with the sensitive phenological stages of the crop causes damage to the crop development. Hence, simple criteria related to sequential phenomenon like dry and wet spells and prediction of probability of onset and termination of the wet season could be used to obtain specific information needed for crop planning and for canying out agricultural operations (Khichar et al., 1991).

Markov Chain probability model has been extensively used to find the long term frequency behavior of wet and dry weather spells (Victor and Sastry, 1979). Pandarinath (1991) used Markov Chain model to study the probability of dry and wet spells in terms of the shortest period like week.

The yield of crops in rain-fed condition depends on the rainfall pattern. Dry and wet spells could be used for analyzing rainfall data, for crop planning and for carrying out agricultural operations (Sharma et al., (1979).

\section{Materials and Methods}

\section{Description of the problem area}

The present study is based on a time series daily rainfall data of 22 years (1998-2019) observed at Samastipur located in Bihar State of India. Pusa Farm is situated in Samastipur district of north Bihar on south of river BurhiGandak. It has a latitude of $25^{\circ} 29^{\prime}$ North and a longitude of $83^{\circ} 48^{\prime}$ East at an altitude of 52.92 meter above sea level. Samastipur faces adverse climatic conditions in summer months with temperature ranging from $35^{\circ} \mathrm{C}$ to $40^{\circ} \mathrm{C}$.

In the winter months, temperature ranges from $10^{\circ} \mathrm{C}$ to $12^{\circ} \mathrm{C}$. The average rainfall is $1200 \mathrm{~mm}$. various factors such as its proximity to the sea influence the weather of Samastipur. The rainfall in this region mostly starts from $23^{\text {rd }} \mathrm{SMW}$ with total duration of 20 weeks till $42^{\text {nd }}$ SMW. Thereafter rainfall amount is meagre for rest of the SMW. Therefore the period from $23^{\text {rd }}$ to $42^{\text {rd }}$ SMW is considered for rainfall analysis.

\section{Onset and withdrawal of rainy season}

The onset of rainy season is computed from weekly rainfall data using Morris and Zandestra, (1979) method using of $75 \mathrm{~mm}$ accumulation as the threshold (Rath et al., 1996, Panigrahi and Panda, 2002; Jat et al., 2003; Deora, 2005), if any week having nil rainfall then restart accumulation of rainfall from SMW.

The withdrawal of rainy season is determined by backward accumulation of rainfall from $52^{\text {nd }}$ SMW accounting to an amount of $10 \mathrm{~mm}$ (Singh and Hazara, 1999; Jat et al., 2005). In the present study backward accumulation of rainfall is considered from $47^{\text {th }} \mathrm{SMW}$ instead of $52^{\text {nd }}$ SMW because post monsoon season is not considered for withdrawal of rainy season. 
If for a longer period (at least 25 years) the weekly rainfall is summed forward and backward from the peak of dry season, until the certain amount calculated, then the probability of given amount of rainfall can be obtained for each time interval chosen. (Dash and Senapati, 1992). Years with respective weeks of onset and withdrawal of rainy season were assigned with the rank number. The probability of each rank was calculated by the following Weibull's formula.

$\boldsymbol{P}=\frac{m}{N+1}$

.......... 1

Where, $\mathrm{m}$ is the rank number and $\mathrm{N}$ is the number of years. For forward accumulation, the rank order and probability level were arranged in ascending order and the corresponding week numbers were arranged in the same manner. Similarly for backward accumulation the rank order and the probability level were arranged in descending order and the corresponding week numbers were arranged in the same way.

\section{Rainfall probabilities by markov chain model}

In a crop growing season, many times decisions have to be taken based on the probability of receiving certain amount of rainfall during a given week $[\mathrm{P}(\mathrm{W})]$, which are called "initial probabilities". Then the probability of rain next week, if we had rain this week $[\mathrm{P}(\mathrm{W} / \mathrm{W})]$; and the probability of next week being wet, if this week is dry $[\mathrm{P}(\mathrm{W} / \mathrm{D})]$ are very important and are called "Conditional probabilities". Analogously, initial and conditional probabilities for a dry week were defined. These initial and conditional probability approaches would help in determining the relative chance of receiving a given amount of rainfall. This becomes the basis for the analysis of rainfall using Markov Chain model.

\section{Initial probability}

The parameters estimated for the analysis were as follows. According to Markov probability model the initial probability is the probability that a particular week of the year is dry or wet under the assumption that the weather of previous week (dry or wet) is not taken into consideration. The initial probability of a week being dry and wet are defined as

$\mathrm{P}_{\mathrm{D}}=\mathrm{F}_{\mathrm{D}} / \mathrm{n}$
$\mathrm{P}_{\mathrm{W}}=\mathrm{F}_{\mathrm{W}} / \mathrm{n}$$\ldots \ldots .2$

Where,

$\mathrm{P}_{\mathrm{D}} \quad=$ Probability of the week being dry,

$\mathrm{P}_{\mathrm{W}}=$ Probability of the week being wet,

$\mathrm{F}_{\mathrm{D}} \quad=$ Number of dry weeks,

$\mathrm{F}_{\mathrm{W}} \quad=$ Number of wet weeks,

$\mathrm{n} \quad=$ Number of years of data

\section{Conditional probabilities}

A conditional probability is the probability that a particular week of the year is dry or wet under the assumption that, the weather of the previous week (dry or wet) is taken into consideration. It indicates the probability of changes in weather from one week to the next week. The conditional probability of a week being dry preceded by another dry week is given by

$\mathrm{P}_{\mathrm{DD}}=\mathrm{F}_{\mathrm{DD}} / \mathrm{F}_{\mathrm{D}} \ldots \ldots .4$
$\mathrm{P}_{\mathrm{WW}}=\mathrm{F}_{\mathrm{WW}} / \mathrm{F}_{\mathrm{W}} \ldots \ldots .5$
$\mathrm{P}_{\mathrm{WD}}=1-\mathrm{P}_{\mathrm{DD}} \ldots \ldots \ldots 6$
$\mathrm{P}_{\mathrm{DW}}=1-\mathrm{P}_{\mathrm{WW}} \ldots \ldots \ldots .7$

Where,

$\mathrm{P}_{\mathrm{DD}}=$ Probability (conditional) of a dry week preceded by a dry week,

$\mathrm{P}_{\mathrm{WW}}=$ Probability (conditional) of a dry week preceded by a wet week,

$\mathrm{P}_{\mathrm{WD}}=$ Probability (conditional) of a wet week preceded by a dry week, 
$\mathrm{P}_{\mathrm{DW}}=$ Probability (conditional) of a dry week preceded by a wet week,

$\mathrm{F}_{\mathrm{DD}}=$ Number of dry weeks preceded by another dry week

$\mathrm{F}_{\mathrm{WW}}=$ Number of dry weeks preceded by another wet week,

\section{Consecutive dry and wet week probabilities}

$2 \mathrm{D}=\mathrm{P}_{\mathrm{Dw} 1} \cdot \mathrm{P}_{\mathrm{DDw} 2}$

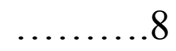

$2 \mathrm{~W}=\mathrm{P}_{\mathrm{Ww} 1} \mathrm{P}_{\mathrm{WWw} 2}$

...........9

$3 \mathrm{D}=\mathrm{P}_{\mathrm{Dw} 1} \cdot \mathrm{P}_{\mathrm{DDw} 2} \cdot \mathrm{P}_{\mathrm{DDw} 3}$

......10

$3 \mathrm{~W}=\mathrm{P}_{\mathrm{Ww} 1} \mathrm{P}_{\mathrm{WWw} 2 .} \mathrm{P}_{\mathrm{WWw} 3}$

Where,

$2 \mathrm{D}=$ Probability of 2 consecutive dry weeks starting with the week,

$2 \mathrm{~W}=$ Probability of 2 consecutive wet weeks starting with the week,

$3 \mathrm{D}=$ Probability of 3 consecutive dry weeks starting with the week,

$3 \mathrm{~W}=$ Probability of 3 consecutive wet weeks starting with the week,

$\mathrm{P}_{\mathrm{Dw} 1}=$ Probability of the week being dry (first week),

$\mathrm{P}_{\mathrm{DDw} 2}=$ Probability of the second week being dry, given the preceding week dry,

$\mathrm{P}_{\mathrm{DDw} 3}=$ Probability of the third week being dry, given the preceding week dry,

$\mathrm{P}_{\mathrm{Ww1}}=$ Probability of the week being wet (first week),

$\mathrm{P}_{\mathrm{WWw} 2}=$ Probability of the second week being wet, given the preceding week wet,

$\mathrm{P}_{\mathrm{Ww} w 3}=$ Probability of the third week being wet, given the preceding week wet,

\section{Results and Discussion}

Estimation of dry and wet weekly probability by using markov chain model

Markov Chain model is used to find out long term frequency behaviour of wet and dry rainfall spells. In the Markov chain model, the probability of an event that would occur on any week depends only on the conditions

during the preceding weeks and is dependent of the events of future weeks. Initial probabilities of occurrence of dry weeks during the different stages of crop growth and conditional probabilities (taking into account the sequential events) provide the basic information on rainfall distribution characteristics necessary for agricultural operations such as irrigation scheduling, fertilizer application. The weekly rainfall data of 22 years (1998-2019) were analyzed to find out initial and conditional probabilities of receiving assured rainfall of 10 and $20 \mathrm{~mm}$ using Markov chain model (Table 1.).

Results revealed that the initial probability of getting $10 \mathrm{~mm}$ rainfall during $23^{\text {th }}$ to $42^{\text {th }}$ SMW are more than $60 \%$ except $39^{\text {th }}, 41^{\text {th }}$ and $42^{\text {th }}$ SMW (Table 1.) whereas conditional probability of wet week preceded by another wet week of getting $10 \mathrm{~mm}$ rainfall during $23^{\text {th }}$ to $40^{\text {th }}$ SMW were $50 \%$ and more. Conditional probability of dry week preceded by another dry week of getting $10 \mathrm{~mm}$ rainfall during $31^{\text {th }}$ to $42^{\text {th }}$ SMW are more than $20 \%$ except $32^{\text {th }}$ and $34^{\text {th }}$ SMW.

Conditional probability of dry week preceded by another wet week of getting $10 \mathrm{~mm}$ rainfall during $23^{\text {th }}$ to $42^{\text {th }}$ SMW are more than $10 \%$ except $32^{\text {th }}$ and $33^{\text {th }}$ SMW. Conditional probabilities of wet week preceded by another dry week of getting 10 $\mathrm{mm}$ rainfall during 23th to 40th SMW are more than $50 \%$ except $33^{\text {th }}$ SMW.

Results revealed that the initial probability of getting $20 \mathrm{~mm}$ rainfall during $23^{\text {th }}$ to $38^{\text {th }}$ SMW are more than $45 \%$ (Table 1.) whereas conditional probability of wet week preceded by another wet week of getting $20 \mathrm{~mm}$ rainfall during $23^{\text {th }}$ to $38^{\text {th }}$ SMW were $45 \%$ and more except $30^{\text {th }}$ and $35^{\text {th }}$ SMW. Conditional probability of dry week preceded by another dry week of getting $20 \mathrm{~mm}$ rainfall during $23^{\text {th }}$ to $42^{\text {th }} \mathrm{SMW}$ are more than $25 \%$ 
except $28^{\text {th }}, 30^{\text {th }}$ and $32^{\text {th }}$ SMW. Conditional probability of dry week preceded by another wet week of getting $20 \mathrm{~mm}$ rainfall during $23^{\text {th }}$ to $42^{\text {th }}$ SMW are more than $20 \%$ except $32^{\text {th }}, 33^{\text {th }}$ and $38^{\text {th }}$ SMW. Conditional probability of wet week preceded by another dry week of getting $20 \mathrm{~mm}$ rainfall during $23^{\text {th }}$ to $40^{\text {th }}$ SMW are more than $40 \%$ except $33^{\text {th }}$ and $37^{\text {th }}$ SMW. The analysis of consecutive dry and wet week revealed that chances of occurrence of $10 \mathrm{~mm}$ and $20 \mathrm{~mm} 2$ consecutive dry weeks are $0-54.55 \%$ and 0 $59.09 \%$ respectively whereas 2 consecutive wet weeks are $0 \%-86.36 \%$ and $0-81.82 \%$ respectively from $23^{\text {th }}$ to $42^{\text {nd }}$ SMW respectively Table (2). The probability of 10 $\mathrm{mm}$ and $20 \mathrm{~mm}, 3$ consecutive dry weeks are $0-54.55 \%$ and $0-59.09 \%$ respectively whereas 3 consecutive wet weeks are $0-72.73 \%$ and 0 $63.64 \%$ respectively from $23^{\text {rd }}$ to $42^{\text {th }}$ SMW respectively. Similar results were obtained by Vanitha and Ravi (2017).

\section{Characteristics of rainy season}

Onset, withdrawal and length of rainy season are worked out by forward and backward accumulation of weekly rainfall data.

Table.1 Initial and Conditional Probabilities of rainfall (10 and $20 \mathrm{~mm}$ ) at Samastipur (1998-2019)

\begin{tabular}{|c|c|c|c|c|c|c|c|c|c|c|}
\hline \multirow{2}{*}{$\mathbf{S M W}$} & \multicolumn{3}{|c|}{$\mathbf{1 0} \mathbf{~ m m}$} & \multicolumn{5}{|c|}{$\mathbf{2 0} \mathbf{~ m m}$} \\
\hline & $\mathrm{P}(\mathrm{W})$ & $\mathrm{P}(\mathrm{D} / \mathrm{D})$ & $\mathrm{P}(\mathrm{D} / \mathrm{W})$ & $\mathrm{P}(\mathrm{W} / \mathrm{W})$ & $\mathrm{P}(\mathrm{W} / \mathrm{D})$ & $\mathrm{P}(\mathrm{W})$ & $\mathrm{P}(\mathrm{D} / \mathrm{D})$ & $\mathrm{P}(\mathrm{D} / \mathrm{W})$ & $\mathrm{P}(\mathrm{W} / \mathrm{W})$ & $\mathrm{P}(\mathrm{W} / \mathrm{D})$ \\
\hline $\mathbf{2 3}$ & 68.18 & 42.86 & 26.67 & 73.33 & 57.14 & 50.00 & 50.00 & 50.00 & 50.00 & 50.00 \\
\hline $\mathbf{2 4}$ & 68.18 & 28.57 & 33.33 & 66.67 & 71.43 & 45.45 & 54.55 & 54.55 & 45.45 & 45.50 \\
\hline $\mathbf{2 5}$ & 81.82 & 14.29 & 20.00 & 80.00 & 85.71 & 72.73 & 25.00 & 30.00 & 70.00 & 75.00 \\
\hline $\mathbf{2 6}$ & 86.36 & 25.00 & 11.11 & 88.89 & 75.00 & 63.64 & 50.00 & 31.25 & 68.75 & 50.00 \\
\hline $\mathbf{2 7}$ & 77.27 & 0.00 & 26.32 & 73.68 & 100.00 & 72.73 & 25.00 & 28.57 & 71.43 & 75.00 \\
\hline $\mathbf{2 8}$ & 81.82 & 0.00 & 23.53 & 76.47 & 100.00 & 72.73 & 16.67 & 31.25 & 68.75 & 83.30 \\
\hline $\mathbf{2 9}$ & 68.18 & 50.00 & 27.78 & 72.22 & 50.00 & 63.64 & 50.00 & 31.25 & 68.75 & 50.00 \\
\hline $\mathbf{3 0}$ & 68.18 & 0.00 & 46.67 & 53.33 & 100.00 & 63.64 & 0.00 & 57.14 & 42.86 & 100.00 \\
\hline $\mathbf{3 1}$ & 81.82 & 28.57 & 13.33 & 86.67 & 71.43 & 59.09 & 50.00 & 35.71 & 64.29 & 50.00 \\
\hline $\mathbf{3 2}$ & 95.45 & 0.00 & 5.56 & 94.44 & 100.00 & 90.91 & 0.00 & 15.38 & 84.62 & 100.00 \\
\hline $\mathbf{3 3}$ & 86.36 & 100.00 & 9.52 & 90.48 & 0.00 & 81.82 & 100.00 & 10.00 & 90.00 & 0.00 \\
\hline $\mathbf{3 4}$ & 86.36 & 0.00 & 15.79 & 84.21 & 100.00 & 72.73 & 50.00 & 22.22 & 77.78 & 50.00 \\
\hline $\mathbf{3 5}$ & 68.18 & 33.33 & 31.58 & 68.42 & 66.67 & 45.45 & 50.00 & 56.25 & 43.75 & 50.00 \\
\hline $\mathbf{3 6}$ & 81.82 & 28.57 & 13.33 & 86.67 & 71.43 & 45.45 & 75.00 & 30.00 & 70.00 & 25.00 \\
\hline $\mathbf{3 7}$ & 68.18 & 25.00 & 33.33 & 66.67 & 75.00 & 50.00 & 66.67 & 30.00 & 70.00 & 33.30 \\
\hline $\mathbf{3 8}$ & 81.82 & 28.57 & 13.33 & 86.67 & 71.43 & 77.27 & 27.27 & 18.18 & 81.82 & 72.70 \\
\hline $\mathbf{3 9}$ & 54.55 & 25.00 & 50.00 & 50.00 & 75.00 & 36.36 & 60.00 & 64.71 & 35.29 & 40.00 \\
\hline $\mathbf{4 0}$ & 63.64 & 30.00 & 41.67 & 58.33 & 70.00 & 31.82 & 57.14 & 87.50 & 12.50 & 42.90 \\
\hline $\mathbf{4 1}$ & 31.82 & 75.00 & 64.29 & 35.71 & 25.00 & 13.64 & 86.67 & 85.71 & 14.29 & 13.30 \\
\hline $\mathbf{4 2}$ & 31.82 & 66.67 & 71.43 & 28.57 & 33.33 & 27.27 & 68.42 & 100.00 & 0.00 & 31.60 \\
\hline
\end{tabular}


Table.2 Consecutive Dry and Wet Probability

\begin{tabular}{|c|c|c|c|c|c|c|c|c|}
\hline \multirow[t]{3}{*}{ SMW } & \multicolumn{4}{|c|}{ Consecutive dry probability (\%) } & \multicolumn{4}{|c|}{ Consecutive wet probability (\%) } \\
\hline & \multicolumn{2}{|c|}{$2 \mathrm{D}$} & \multicolumn{2}{|c|}{$3 \mathrm{D}$} & \multicolumn{2}{|c|}{$2 \mathrm{~W}$} & \multicolumn{2}{|c|}{$3 \mathrm{~W}$} \\
\hline & $\begin{array}{c}10 \\
\mathrm{~mm}\end{array}$ & $\begin{array}{c}20 \\
\mathrm{~mm}\end{array}$ & $\begin{array}{c}10 \\
\mathrm{~mm}\end{array}$ & $\begin{array}{c}20 \\
\mathrm{~mm}\end{array}$ & $\begin{array}{c}10 \\
\mathrm{~mm}\end{array}$ & $\begin{array}{c}20 \\
\mathrm{Mm}\end{array}$ & $\begin{array}{c}10 \\
\mathrm{~mm}\end{array}$ & $\begin{array}{c}20 \\
\mathrm{~mm}\end{array}$ \\
\hline 23 & 9.09 & 27.27 & 1.30 & 6.82 & 45.45 & 22.73 & 36.36 & 15.91 \\
\hline 24 & 4.55 & 13.64 & 1.14 & 6.82 & 54.55 & 31.82 & 48.48 & 21.88 \\
\hline 25 & 4.55 & 13.64 & 0.00 & 3.41 & 72.73 & 50.00 & 53.59 & 35.71 \\
\hline 26 & 0.00 & 9.09 & 0.00 & 1.52 & 63.64 & 45.45 & 48.66 & 31.25 \\
\hline 27 & 0.00 & 4.55 & 0.00 & 2.27 & 59.09 & 50.00 & 42.68 & 34.38 \\
\hline 28 & 9.09 & 13.64 & 0.00 & 0.00 & 59.09 & 50.00 & 31.52 & 21.43 \\
\hline 29 & 0.00 & 0.00 & 0.00 & 0.00 & 36.36 & 27.27 & 31.52 & 17.53 \\
\hline 30 & 9.09 & 18.18 & 0.00 & 0.00 & 59.09 & 40.91 & 55.81 & 34.62 \\
\hline 31 & 0.00 & 0.00 & 0.00 & 0.00 & 77.27 & 50.00 & 69.91 & 45.00 \\
\hline 32 & 4.55 & 9.09 & 0.00 & 4.55 & 86.36 & 81.82 & 72.73 & 63.64 \\
\hline 33 & 0.00 & 9.09 & 0.00 & 4.55 & 72.73 & 63.64 & 49.76 & 27.84 \\
\hline 34 & 4.55 & 13.64 & 1.30 & 10.23 & 59.09 & 31.82 & 51.21 & 22.27 \\
\hline 35 & 9.09 & 40.91 & 2.27 & 27.27 & 59.09 & 31.82 & 39.39 & 22.27 \\
\hline 36 & 4.55 & 36.36 & 1.30 & 9.92 & 54.55 & 31.82 & 47.27 & 26.03 \\
\hline 37 & 9.09 & 13.64 & 2.27 & 8.18 & 59.09 & 40.91 & 29.55 & 14.44 \\
\hline 38 & 4.55 & 13.64 & 1.36 & 7.79 & 40.91 & 27.27 & 23.86 & 3.41 \\
\hline 39 & 13.64 & 36.36 & 10.23 & 31.52 & 31.82 & 4.55 & 11.36 & 0.65 \\
\hline 40 & 27.27 & 59.09 & 18.18 & 40.43 & 22.73 & 4.55 & 6.49 & 0.00 \\
\hline 41 & 45.45 & 59.09 & 36.36 & 48.01 & 9.09 & 0.00 & 0.00 & 0.00 \\
\hline 42 & 54.55 & 59.09 & 54.55 & 59.09 & 0.00 & 0.00 & 0.00 & 0.00 \\
\hline
\end{tabular}


Table.3 Onset and withdrawal of rainy season at Junagadh

\begin{tabular}{|c|c|c|}
\hline \multirow{2}{*}{ Year } & Onset & Withdrawal \\
\hline $\mathbf{1 9 9 8}$ & $75 \mathrm{~mm}$ & $10 \mathrm{~mm}$ \\
\hline $\mathbf{1 9 9 9}$ & 26 & 46 \\
\hline $\mathbf{2 0 0 0}$ & 25 & 40 \\
\hline $\mathbf{2 0 0 1}$ & 22 & 43 \\
\hline $\mathbf{2 0 0 2}$ & 19 & 40 \\
\hline $\mathbf{2 0 0 3}$ & 23 & 43 \\
\hline $\mathbf{2 0 0 4}$ & 22 & 38 \\
\hline $\mathbf{2 0 0 5}$ & 25 & 43 \\
\hline $\mathbf{2 0 0 6}$ & 23 & 42 \\
\hline $\mathbf{2 0 0 7}$ & 24 & 45 \\
\hline $\mathbf{2 0 0 8}$ & 23 & 40 \\
\hline $\mathbf{2 0 0 9}$ & 19 & 41 \\
\hline $\mathbf{2 0 1 0}$ & 21 & 42 \\
\hline $\mathbf{2 0 1 1}$ & 22 & 42 \\
\hline $\mathbf{2 0 1 2}$ & 26 & 41 \\
\hline $\mathbf{2 0 1 3}$ & 22 & 41 \\
\hline $\mathbf{2 0 1 4}$ & 23 & 42 \\
\hline $\mathbf{2 0 1 5}$ & 21 & 42 \\
\hline $\mathbf{2 0 1 6}$ & 18 & 40 \\
\hline $\mathbf{2 0 1 7}$ & 22 & 38 \\
\hline $\mathbf{2 0 1 8}$ & 20 & 40 \\
\hline $\mathbf{2 0 1 9}$ & 27 & 50 \\
\hline & & \\
\hline
\end{tabular}

Table.4 Characteristics of the rainy season at Junagadh

\begin{tabular}{|c|c|c|c|c|c|}
\hline \multicolumn{2}{|c|}{$\begin{array}{c}\text { Onset of rainy season } \\
\text { (week) }\end{array}$} & \multicolumn{2}{|c|}{$\begin{array}{c}\text { Withdrawal of rainy season } \\
\text { (week) }\end{array}$} & \multicolumn{2}{c|}{$\begin{array}{c}\text { Length of rainy season } \\
\text { (week) }\end{array}$} \\
\hline Early & Late & Early & Late & Maximum & Minimum \\
\hline $\mathbf{1 8}$ & 27 & 38 & 50 & 23 & 15 \\
\hline
\end{tabular}

Table.5 Probability of the onset of rainy season during standard week

\begin{tabular}{|l|c|c|c|c|c|c|c|c|c|c|}
\hline \multicolumn{1}{|c|}{ SMW } & $\mathbf{1 8}$ & $\mathbf{1 9}$ & $\mathbf{2 0}$ & $\mathbf{2 1}$ & $\mathbf{2 2}$ & $\mathbf{2 3}$ & $\mathbf{2 4}$ & $\mathbf{2 5}$ & $\mathbf{2 6}$ & $\mathbf{2 7}$ \\
\hline $\begin{array}{l}\text { Probability of } \\
\text { onset of rainy } \\
\text { season (\%) }\end{array}$ & 9.09 & 18.18 & 27.28 & 36.37 & 45.46 & 54.55 & 63.64 & 81.82 & 88.20 & 90.91 \\
\hline
\end{tabular}




\section{Onset of rainy season}

In the beginning of the rainy season, there should be adequate rainfall for land preparation and sowing of crops. The onset of the rainy season is considered as the week by which the rainfall accumulates to $75 \mathrm{~mm}$ after $20^{\text {th }}$ week. If any week having nil rainfall than restart accumulation of rainfall.

The standard meteorological week during which rainy season started in respective year is shown in Table 3. Considerable variation in the onset of rainy season occurs during the years. From Table 4, it is evident that early onset of rainy season is at $18^{\text {th }}$ week and maximum delay is up to $27^{\text {th }}$ week. The percentage probabilities for onset of rainy season during different standard meteorological weeks are presented in Table 5. Probability at $25^{\text {th }}$ week is found to be $81.82 \%$ which may be supposed as mean standard week of onset of rainy season.

\section{Withdrawal of rainy season}

Withdrawal of rainy season is determined by backward accumulation of rainfall from $52^{\text {th }}$ week accounting to an amount of $10 \mathrm{~mm}$ rainfall as suggested by Morris and Zandestra, (1979) are presented in Table 3. Table-3 shows the withdrawal of rainy season in different years and Table 2.Shows early and late weeks of withdrawal of rainy season.

From these tables it can be seen that earliest withdrawal of rainy season is in $38^{\text {th }}$ week, late withdrawal of rainy season in $50^{\text {th }}$ week. Probabilities of onset of rainy season are shown in Table 5. Probability in $25^{\text {th }}$ week is found to be $81.25 \%$, which may be considering onset of rainy season.

The results revealed that the determined withdrawal of monsoon is observed in 35 SMW during the year 1987 and 2009, while the crop growth period terminates in $47^{\text {th }}$ SMW considering the observed onset of monsoon (28 $\left.{ }^{\text {th }} \mathrm{SMW}\right)$ and groundnut crop having maximum length of growing season of 18 weeks.

Therefore, it is observed that rainfall during whole post monsoon season considered for withdrawal of rainy season is not justified. Therefore backward accumulation of rainfall should be considered from $47^{\text {th }}$ SMW rather than $52^{\text {nd }}$ SMW. Similar results were obtained by Singh et al., (2014).

\section{Length of rainy season}

The length of rainy season is the period between onset and withdrawal of the rainy season. Length of rainy season for Samastipur shown in Table 4. Minimum length of rainy season is found to be 15 week during 2012 and maximum length of raining season is found 23 weeks in 2019.

The initial and conditional probability of getting $20 \mathrm{~mm}$ per week in $25 \mathrm{SMW}$ is $81.82 \%$. Therefore sowing should be carried out in this week.

The probability of two and three consecutive dry weeks having $10 \mathrm{~mm}$ per week threshold limit is more than $27 \%$ and $54 \%$ respectively after $39^{\text {th }}$ SMW. Hence irrigation should be applied to the crops during these periods.

Conditional probability of wet week preceded by wet week having $20 \mathrm{~mm}$ threshold limit is more than $60 \%$ in $25^{\text {th }}$ to $38^{\text {th }}$ SMW. Therefore it is the optimal time for water harvesting for supplementary irrigation to crops in moisture deficit period.

Minimum length of rainy season is found to be 15 week during 2012 and maximum length of raining season is found 23 weeks in 2019. 


\section{Abbreviation and symbol}

$\begin{array}{ll}\mathrm{cm} & \text { Centimeter } \\ \mathrm{h} & \text { Hour } \\ \mathrm{m} & \text { meter } \\ \% & \text { Percentage } \\ \& & \text { And } \\ \mathrm{mm} & \text { millimeter } \\ \circ & \text { Degree } \\ \mathrm{T} & \text { Return Period } \\ { }^{\circ} \mathrm{C} & \text { Degree Celsius } \\ \text { Mha Million hectares } \\ \text { MCM Million Cubic Meter } \\ \text { SMW Standard Metrological Week } \\ \text { 2D } & \text { Two consecutive dry weeks } \\ \text { 2W Two consecutive wet weeks } \\ \text { P(W) Probability of wet weeks } \\ \text { P(D) Probability of dry weeks }\end{array}$

\section{Application of research}

Weekly rainfall analysis by markov chain model for crop playing in Samastipur district of Bihar

\section{References}

Dash, M. K. and Senapati, P. C. (1992). Forecasting of dry and wet spell at Bhubaneswar for Agricultural planning. Indian Journal of Soil Conservation, 20(142):75-82

Jat, L, Singh, R. V., Balyan, J. K. and Jain, L. K. (2005). Analysis of Weekly Rainfall for Crop Planning in Udaipur Region, Journal of Agricultural Engineering, 42(2): 166-169.

Jat, M. L., Singh, R. V., Kumpawat, B. S. and Balyan, J. K. (2003). Rainy season and its variability for crop planning in Udaipur region. Journal of Agrometrology, 5(2):82-86.

Khichar, M. L., Singh, R. and Rao. V. D. M. (1991). Water availability periods for crop planning in Haryana. International Journal of Tropical
Agriculture, 1(4):301-305.

Morris, R. A. and Zandstra, H. G. (1979). Land and climatic in relation to cropping patterns. In rainfed low land rice, selected papers from 1970. International Rice Research Conference.IRRI, 255-274.

Pandatinath, N. (1991). Markov chain model probability of Dry and wet weeks during monsoon periods over Andhra Pradesh. Mausam, 42 (4):393-400.

Panigrahi, B. and Panda, S. N. (2002) Analysis of weekly rainfed for crop planning in rainfed region. Journal of Agricultural Engineering, (ISAE), 38(4): 47-57.

Parthasarathy, R. (2009). State level water section interventions - Gujarat State, International Water Management Institute -TATA Water Policy Research Program.

Rath, H., Jena, G. N. and Senapati, P. C. (1996) Forecasting of dry and wet spells at Boudh for agricultural planning. Indian Journal of Soil Conservation, 24(1):28-36.

Sharma, H. C., Chauhan, H. S. and Ram, S. (1979). Probability analysis of rainfall for crop planning. Journal of Agricultural Engineering, 14: 87-94.

http://finance.bih.nic.in/Budget/EconomicSurvey-2012

Singh, R. S., Patel, C.,Yadav, M. K., Singh, P. K. and Singh, K. K. (2014). Weekly Rainfall Analysis and Markov Chain Model Probability of Dry and Wet Weeks at Varanasi in Uttar Pradesh. Journal of Environment \& Ecology, 32 (3): 885-890,

Vanitha, S. and Ravikumar, V. (2017). Weekly Rainfall Analysis for Crop Planning Using Markov's Chain Model for Kumulur. International Journal of Agriculture Sciences, 9(42):4679-4682.

Victor, U. S. and Sastri., P. S. N.(1979). Dry 
spell probability by Markov chain model and its application to crop development stages. Indian Journal of
Meteorology, Hydrologyand Geophysics. 30(4):479-489.

\section{How to cite this article:}

Pappu Kumar Paswan, Ved Prakesh Kumar, Andhale Anil Nanasaheb and Abhishek Pratap $\mathrm{Singh}^{4}$. 2020. Weekly Rainfall Analysis by Markov Chain Model in Samastipur District of Bihar. Int.J.Curr.Microbiol.App.Sci. 9(05): 57-66.

doi: https://doi.org/10.20546/ijcmas.2020.905.005 